\title{
John Baconthorpe on Soul, Body and Extension
}

Simon F. Nolan

\begin{abstract}
:
John Baconthorpe (c.1290-1345/8) was the best-known of the Carmelite scholastics in the Middle Ages. This article is a brief study of his solution to the philosophical problem of how the soul may be wholly present in the human body and present whole and undivided in each part. Baconthorpe's account is of great interest for a number of reasons. He takes issue with one of his fellow Carmelite masters, alerting us to diversity of opinion within that 'school'. Furthermore, in using terminology and illustrative analogies drawn from terminist logic and the mathematical sciences, Baconthorpe is an important witness to what has been described as the 'mathematization' of philosophy and theology in late medieval England. Finally, study of Baconthorpe's texts provides further evidence of the emergence of the theme of extension in fourteenth-century thought in which we can discern the roots of modern philosophical debate.
\end{abstract}

\section{Introduction}

In Plato's Phaedrus Socrates declares: 'to describe what the soul actually is would require a long account, altogether a task for a god in every way." ${ }^{100}$ Unperturbed, many thinkers over the ages have attempted this 'god-like' task of giving a philosophical account of the soul and, more particularly, its relationship to the body.

In the late Middle Ages much of the philosophical discussion concerning the relationship between the soul and the body concerned itself with three problems. First, there was the interaction problem: how do soul and body interact with one another in a causal way given they are such different substances? Secondly, there was the unification problem: how could soul and body, such apparently separate and diverse substances, be united under the identity of a unique and unified entity such as, for example, a human being? Thirdly, there was the extension problem: how could the soul, as the form of the body, be present as a whole in every part of the body without being subject to spatial extension?

In the early fourteenth-century thinkers placed particular emphasis on the extension problem and considered it within the context of a wider concern to articulate a metaphysics of presence. The challenge to Eucharistic theology to give an account of the natural extension of Christ's body which is manifestly not circumscribed in the Sacrament was seen to be analogous to the difficulty of explaining how the soul is present in the body in a dynamic way without itself being spatially extended. ${ }^{101}$

${ }^{100}$ Plato, Phaedrus 246a, transl A. Nehamas and P. Woodruff in Plato: Complete Works, ed. J. M. Cooper (Indianapolis: Hackett, 1997) p. 524.

101 See P.J.J.M. Bakker, La raison et le miracle: les doctrines eucharistiques (c.1250-c.1400). Contribution à l'étude des rapports entre philosophie et théologie (Nijmegen: Katholieke 
For many late medieval thinkers the key to dealing with such problems of presence and extension was to posit a forma corporeitatis or 'corporeal form' in addition to the rational soul and thereby insist upon a plurality of substantial form in the human being. Some kind of form of the body or of 'bodiliness' was considered necessary to underscore the theological doctrines of the resurrection and the cult of relics; the issue was that of asserting the numerical identity of the human body through life, death and resurrection. In time to assert the contrary position and to insist (along with a thinker such as Thomas Aquinas (d.1274)) on the unicity of substantial form was to incur official censure. Although a condemnation of the unicity theory is absent from the Parisian condemnation of 1277, Archbishop of Canterbury, John Peckham's 1286 condemnation explicitly targeted it. ${ }^{102}$

The subject of this article, the Carmelite John Baconthorpe, conforms to the plurality thesis in relation to substantial form. There is nothing remarkable about this but what is interesting is the way in which he sees the potential in the plurality thesis for extricating the rational soul from issues of spatial extension. Equally intriguing are the kind of analogies Baconthorpe employs in his attempt to solve the extension problem by explaining the way in which the rational soul may be wholly present as form of the body and present as a whole in every part of the human being.

Study of John Baconthorpe on soul, body and extension is important for a number of reasons. First, paying attention to early Carmelite scholastics such as Baconthorpe is an indispensible part of the current move among scholars of medieval philosophy to deepen our understanding of the intellectual history of the early fourteenth-century, thus moving away from the 'Gilsonian paradigm' of thirteenthcentury superiority. Secondly, reading Baconthorpe on the relationship between body and soul provides us with an example of early dispute among Carmelite doctors: Baconthorpe takes issue with the views of Gerard of Bologna, first Carmelite doctor at the University of Paris and former Prior General of the Order, who advocated the unicity of substantial form in human beings. Thirdly, Baconthorpe is an important witness to a discernible change in philosophical terminology which takes place at the beginning of the fourteenth century. Philosophical discussions of the period become replete with 'extension-type' language. Previously there was ample discussion concerning quantity, the subject of quantity, quantity's role in individuation and the relationship between whole and parts. The fourteenth-century focus in thought and in terminology on issues of extension helps to build up a picture of very real continuity of discussion in medieval, Renaissance and modern thought. ${ }^{103}$ Fourthly, reading Baconthorpe's discussion of soul body and extension is a contribution to the

Universiteit, 1999). Also K. Plotnik, Hervaeus Natalis OP and the Controversies over the Real Presence and Transubstantiation (Munich-Paderborn-Vienna: F. Schönigh Verlag, 1970).

${ }^{102}$ For a discussion of the philosophical and theological controversy surrounding the unicityplurality of substantial form see Caroline Walker Bynum, The Resurrection of the Body in Western Christianity, 200-1336 (New York-Chichester: Columbia University Press, 1995).

${ }^{103}$ See D. Des Chene, Life's Form: Late Aristotelian Conceptions of the Soul (Ithaca-London: Cornell University Press, 2000), especially Chapter 9 'Divisible Souls', pp. 171-189, for a survey of discussion of soul, body and extension among Renaissance thinkers. With an eye to continuity of the debate into later centuries Des Chene highlights (p. 171, n. 2) the later exasperation of Pierre Gassendi when faced with (what Gassendi regarded as) Descartes's dogmatism in asserting that mind must not be extended without much supporting argument. 
wider medieval preoccupation with the metaphysics of presence. Fifthly, Baconthorpe's style of argumentation, employing as it does terminology and illustrative examples from 'the exact sciences' (such as geometry) gives us some insight into the way English theologians liked to do their theology with their strong background in the mathematical sciences. In short, Baconthorpe is an important witness to what William Courtenay has described as the 'mathematisation of theology' in England in the late medieval period; it will be noted later in this article that the terminology the Carmelite master employs shows a certain affinity with that of the Oxford Mertonists. ${ }^{104}$ Finally, reading Baconthorpe helps us to trace the impact of the Condemnations of 1277 and 1286 on the subsequent development of thought.

After a brief presentation of the life and work of Baconthorpe, some consideration will be given to the position of Gerard of Bologna since Baconthorpe articulates his own views in reaction to those of his Carmelite confrere. Then Baconthorpe's solution to the problem of soul, body and extension will be presented and followed by some concluding remarks.

\section{John Baconthorpe}

The best-known of the early Carmelite scholastics, John Baconthorpe, was born in England around $1290 .{ }^{105}$ In the past scholars have suggested that he read the Sentences

104 W.J. Courtenay, Schools and Scholars in Fourteenth-century England (Princeton NJ: Princeton University Press, 1987), pp. 258-262. Edward Grant points to the profound differences between English universities and the university of Paris in relation to the study of the exact sciences in the thirteenth and fourteenth centuries: 'The emphasis on the exact sciences was not, however, of equal breadth and scope in all medieval universities. Although they formed an integral part of the curriculum at Oxford from the thirteenth century onward, they received much less emphasis at Paris and other places. For example, mathematics was not regularly taught at Paris in the thirteenth century and only sporadically in the fourteenth.' (E. Grant, The Nature of Natural Philosophy in the Late Middle Ages (Washington DC: Catholic University of America Press, 2010), p. 20). Elsbieta Jung highlights the 'new theology' which emerged in England as result of the engagement with the exact sciences on the part of theologians: 'There were three main disciplines in which Englishmen were the leaders: terminist logic, mathematical physics and a new theology based on methods and insights achieved in the first two areas.' (E. Jung, 'The Concept of Time in Richard Kilvington' in G.Alliney and L. Cova, eds., La concettualizzazione del tempo nel pensiero tardomedievale. Atti de Colloquio internazionale (Trieste, 4-6 marzo 1999) (Firenze: Olshki, 2000), pp. 187-205, p. 187). John Baconthorpe can be seen to be a proponent of this innovative approach among English scholars.

${ }^{105}$ For studies of John Baconthorpe, Doctor resolutus, see the following: S. Nolan, John Baconthorpe' in H. Lagerlund, ed., Encyclopedia of Medieval Philosophy, (Dordrecht: Springer, 2011), pp. 594-597; R. Cross, 'John Baconthorpe', in Jorge J. E. Gracia and Timothy B. Noone, eds., A Companion to Philosophy in the Middle Ages, (Malden MA-Oxford: Blackwell, 2003), pp. 338-339; J. Etzwiler, 'Baconthorpe and Latin Averroism: the Doctrine of the Unique Intellect', in Carmelus 18 (1979), pp. 235-292; J. Etzwiler, 'John Baconthorpe: 'Prince of the Averroists?', in Franciscan Studies 36 (1976), pp. 148-176; L. Kennedy, 'John Baconthorpe O.Carm. and Divine Absolute Power', in Carmelus 38 (1991), pp. 63-68; M.C. Linenbrink, 'The Universal and Its Relation to the Phantasised Object According to John 
of Peter Lombard at Paris before 1318. However, recent scholarship proposes 132021 as a more likely dating. Baconthorpe had incepted as master in the theology faculty at Paris by $1323 .{ }^{106} \mathrm{He}$ edited his commentary on the Sentences around 1325. Baconthorpe's three sets of Quaestiones quodlibetales were disputed from 1323 to 1325 and in 1330: Quodlibet I (1323-1324), Quodlibet II (1324-1325), Quodlibet III (1330). He produced a second redaction of his commentary on book IV of the Sentences around 1340. Baconthorpe was Prior Provincial of the Carmelites in England from 1327 (possibly 1326) to 1333 and taught at Cambridge and probably at Oxford. He died around 1348 (possibly of Plague). Baconthorpe's teaching was so highly regarded in his order that both his Sentences commentary and his Quodlibeta were printed several times in the early modern era. Indeed by the seventeenth century he had effectively become the 'official' theologian of the Carmelites. Key to his status as preeminent Carmelite theologian was his defence of the doctrine of the Immaculate Conception and his writings concerning the history and spiritual tradition of his order and the importance of its early thirteenth-century Rule. Later English Carmelite scholastics, Osbert Pickenham (late $14^{\text {th }}$ century) and Richard Lavenham (d. 1399), both cite a commentary on Aristotle's De anima by Baconthorpe but this is not known to survive. ${ }^{107}$

In common with other early Carmelite scholastics, Baconthorpe reveals himself to be a consistent if somewhat eclectic thinker. His own thinking is most often developed in dialogue with the thought of major figures such as Henry of Ghent (c.1217-1293), John Duns Scotus (c.1266-1308) and Peter Auriol (c.12801322). Baconthorpe frequently takes issue with Thomas Aquinas and both presents and criticises key doctrines of Giles of Rome (c.1247-1316) and Godfrey of Fontaines (c.1250-1304). Baconthorpe was an opponens of Thomas Bradwardine (c.1290-1349), specifically on the issue of freewill and predestination. An interesting aspect of his work is Baconthorpe's willingness to engage critically with the thought of other Carmelite scholastics such as Gerard of Bologna (d.1317) and his one-time Carmelite teachers at Paris and Oxford, Guido Terreni (d.1342) and Robert Walsingham (d.1313).

Throughout his work Baconthorpe is keen to present himself as a true interpreter of Aristotle. Frequently he is content to settle an argument secundum Philosophum without much supporting theological discussion; the text we will refer to later is a classic example of this. Another characteristic of Baconthorpe's thinking is his tendency to conclude his arguments at key points with the aid of Averroes's commentaries. This led to his being given the rather exaggerated title Princeps

Baconthorp', in The Modern Schoolman 42 (1965), pp. 353-374; C. Schabel, 'Carmelite Quodlibeta' in Christopher Schabel, ed., Theological Quodlibeta in the Middle Ages: The Fourteenth Century, Leiden: E.J. Brill, 2007, pp. 493-541; J. Wippel (1994) 'Godfrey of Fontaines (b. ca. 1250; d. 1306/09), Peter of Auvergne (d. 1303), and John Baconthorpe (d. 1345/48) in Jorge J. E. Gracia, ed., Individuation in Scholasticism: The Later Middle Ages and the Counter-Reformation 1150-1650 (Albany NY: State University of New York Press, 1994), pp. 221-256; B. Xiberta (1931) De scriptoribus scholasticis saeculi XIV ex ordine Carmelitarum (Louvain: 1931), pp. 167-240.

${ }^{106}$ See C. Schabel, 'Carmelite Quodlibeta', pp. 493-541.

${ }^{107}$ R. Sharpe, A Handlist of Latin Writers of Great Britain and Ireland before 1540 (Turnhout: Brepols, 2012), p. 208. 
Averroistarum in sixteenth-century Padua in the Libellus de immortalitate animae of Agostino Nifo (c.1469-1538). ${ }^{108}$ It has to be said that Baconthorpe's title as 'Prince [or 'chief'] of the Averroists' has little really to do with his overall doctrinal affiliations and is more a recognition of his skill in explaining the doctrine of Averroes, particularly concerning the unique intellect. Baconthorpe's undeniable eclecticism may deny to his works the last degree of originality but it does give rise to a strong positive commitment on his part to the meticulous presentation of the opinions of other scholastics in preparation for declaring his own position. For this reason Baconthorpe's works are highly significant for the insight they afford into the state of philosophical and theological debate in the early fourteenth century.

\section{Gerard of Bologna}

Baconthorpe articulates his own views on soul, body and extension in reaction to the views of an earlier Carmelite scholastic, Gerard of Bologna, the first Carmelite master at the University of Paris in the Middle Ages, who incepts in 1295, becoming Prior General of the Order in 1297. ${ }^{109}$ Unlike Baconthorpe, Gerard advocated the unicity of substantial form; in other words, he does not argue for corporeal form in addition to the rational soul. However, this led him to be wonder whether this might not lead one to having to say that the rational soul, as unique form of the body in human beings, is in some way extended along with the extension of matter, quantity being one of the Aristotelian categories of accident. Gerard deals with the issue in his Quodlibet II, q. 19 (c.1307) and (at considerable length) in Quodlibet III, q. 7 (c. 1308). His ultimate position is agnostic: he can see plenty of arguments for the position that the soul might be extended per accidens but is completely at a loss to determine the issue.

Gerard's position attracted significant contemporary comment. He was strongly opposed on the issue by the Dominican Hervaeus Natalis (c.1250-1323), an early promotor of the doctrines of Thomas Aquinas within his Order. ${ }^{110}$ In addition, the anonymous Scotist of Vat. Lat. 869 is an important source for contemporary reaction to Gerard's doctrine concerning the soul. ${ }^{111}$ This author claims to have heard (audivi) Gerard of Bologna and Francis Caracciolo, the Chancellor of the University of Paris from 1309 to 1316, maintain that the rational soul is extended per accidens and that, furthermore, the contrary can only be held as a matter of faith. The author

${ }^{108}$ J. P. Etzwiler, 'John Baconthorpe 'Prince of the Averroists', in Franciscan Studies 36 (1976), pp. 148176.

${ }^{109}$ See S. Nolan, 'Teaching and Learning in the Summa theologiae of Gerard of Bologna (d. 1317)' in Maynooth Philosophical Papers, 5 (2008), pp. 35-41.

${ }^{110}$ Hervaeus's argument with Gerard of Bologna focuses on the point that in the case of the Eucharist dimensive quantity does not entail external extension. See Hervaus Natalis, Quodlibeta (Venice: 1513; reprint Ridgewood NJ: Gregg Press, 1966), Quodlibet II, q. 10, 52 va.

${ }^{111}$ See S.D. Dumont, 'The Scotist of Vat. lat. 869,' in Archivum Franciscanum Historicum 81 (1988), pp. 254-83. 
clearly considers such a conclusion results from a denial of plurality of substantial form (supposito quod in bomine non sit nisi una forma sola). ${ }^{112}$

Later the author goes on to say that another doctor thought that Gerard's position on the extension of the soul was heretical: Sed contra istos doctores invebebat unus alius doctor, dicens quod illud erat periculose dictum et sapiebat heresim, videbatur enim declinare ad opinionem Commentatoris, qui posuit animam intellectivam esse corpoream. ${ }^{113}$ ('But against those doctors one other doctor went on the attack, saying that this was a dangerous opinion and that it smacked of heresy and seemed to decline unto the opinion of Averroes who held the rational soul to be corporeal.')

\section{Baconthorpe's Solution}

Our text comes from Baconthorpe's redacted commentary on Book III of the Sentences of Peter Lombard (In Tertium Sent., d. 18, q. 1, 1-3). ${ }^{114}$ As we suggested previously, it may be dated to somewhere around 1325. It comes in the form of a quaestio divided into three articles. Here Baconthorpe sets out explicitly to counter the opinion of his Carmelite predecessor, Gerard of Bologna, that the soul might be accidentally extended and suggests ways one might argue philosophically for the presence of the soul as whole in whole and whole in each part. Baconthorpe's general approach will be to insist that corporeal form (forma corporeitatis) together with prime matter can 'take care of' issues of spatial extension, leaving the rational soul to fulfil its 'higher calling' to extend itself as a power in the human body, a power which is whole in the whole and whole in each part.

\footnotetext{
${ }^{112}$ The full text of the anonymous author's observations is as follows: 'Ad istam quaestionem audivi duos reverendos viros at theologiae magistros (Cancellarius et Carmelita in marg.) dicere quod, supposito quod in homine non sit nisi una forma sola, fide tenebant animam intellectivam esse $\mathrm{ab}$ extrinseco, $<\mathrm{et}>$ tenent animam intellectivam esse inextensam per se et per accidens, et hoc quod sola < fide $>$ tenendum sit et non possit ostendi per rationem, se potius oppositum probant unica ratione quam dicunt se nescire solvere. Et ratio est ista: quando aliquid convenit alicui toti primo necessario convenit cuilibet parti aliquo modo. Sed homini, inquantum dicit aliquid compositum ex materia et forma substantiali, et non tamen inquantum est materia tantum, convenit primo esse extensum, dicente Philosopho I Physicorum 'subiecta materia cum forma est causa sicut mater', id est subiectiva omnium accidentium. Ergo quaelibet pars hominis de necessitate est aliquo modo extensa. Cum ergo anima intellectiva sit pars talis totius cui primo convenit esse extensum, quia non est in illa toto cui primo convenit esse extensum alia forma nisi intellectiva, sit aliquo extensa.' (Quoted in Dumont 'Scotist of 869' p. 275).

${ }^{113}$ Quoted in S.F. Brown and S.D. Dumont, 'Univocity of the Concept of Being in the Fourteenth Century: III. An Early Scotist' in Medieval Studies 51 (1989) pp. 1-129, pp. 5-6, n. 16.

${ }^{114}$ John Baconthorpe, Quaestiones in quatuor libros sententiarum et quodlibetales, 2 vols, Cremona: 1618, 115a-119a.
} 


\section{Article 1}

The first article sets out to answer the question of whether the rational soul may be the substantial form of every part of the human body and of the whole human body and not be spatially extended.

Turning to the opinions of his Carmelite predecessor, Gerard of Bologna, Baconthorpe argues his own position. He declares: 'I concede that the whole composite, which is subjected to quantity and informed by it, namely the human being, is extended accidentally. ${ }^{115}$ So it is the human being as a whole, as a unified composite of matter and form, body and soul, that can be said to be extended accidentally. He goes on to insist that the only parts of that composite that are really extended accidentally are matter together with corporeal form:

And when it is said that essential parts are also extended accidentally, I say that that essential part which is the proximate and immediate principle of accepting extension (namely, matter together with the corporeal form) is extended accidentally, and this part which is the first and principal ratio of receiving extension is not extended accidentally in reality but only equipollently, namely in so far as equally truly it is in each part of extended matter. ${ }^{116}$

The use of the term 'equipollently' is unusual here. 'Equipollence' is a common term in the terminist logic of the late medieval period and has to do with the equivalence and convertability of propositions (equipollentia propositionum). ${ }^{117}$ Here the Carmelite master is employing the term in a metaphysical-psychological context to mean that the soul is of equal 'power' in the whole body and in each and every part of the body in which it is present. Here we have a fine example of the tendency among English scholars in the thirteenth and fourteenth centuries to introduce terminology from terminist logic and the exact sciences into philosophical and theological discourse.

Matter and corporeal form are the proximate and immediate rationes of receiving extension. But there is, Baconthorpe argues, a prior first and principal ratio, namely the rational soul, which more remotely might be said to receive extension but does

${ }^{115}$ Concedo quod totum compositum, quod subiicitur quantitati, et informatur per eam, scilicet homo, istud extenditur per accidens. (115b).

${ }^{116}$ Et quando dicitur, quod etiam partes essentiales extenduntur per accidens, dico quod illa pars essentialis, quae est proxima, et immediata ratio excipiendi extensionem (scilicet materia et forma corporeitatis) extenditur per accidens, pars autem, quae est prima, et principalis ratio excipiendi extensionem non extenditur per accidens realiter, sed solum per aequipollentiam, scilicet inquantum aeque vere est in qualibet parte materiae extensae, ac si extenderetur. (115b).

${ }_{117}$ Paul Vincent Spade highlights several instances of medieval discussion of equipollence of propositions. See P.V. Spade, Thoughts, Words and Things: An Introduction to Late Medieval Logic and Semantic Theory, Version 1.2: http://www.pvspade.com/Logic/docs/Thoughts, Words and Things1 2.pdf. John Buridan (c.1295-1361) includes a substantial discussion of aequipollentia propositionum in his Summulae de dialectica, Treatise 1, Chapter 5 wherein he sets out four rules of equipollence. See J. Buridan, Summulae de dialectica: An Annotated Translation with a Philosophical Introduction, ed. Gyula Klima, (Yale: Yale University Press, 2001). 
not do so in reality (realiter) but only equipollently. The rational soul is whole and whole in every part of extended matter. In other words, Baconthorpe is trying to argue that the rational soul as the principle of life of the whole human composite of body and soul is whole and whole in every part and is in this way extended. But it is not spatially extended. Such spatial extension or quantity is, for Baconthorpe, 'taken care of' by matter and corporeal form.

Next Baconthorpe considers the suggestion of Gerard that the whole human being is extended: totus homo est extensus. Here he more or less repeats the same argumentation as above in response to the question in quo recipitur quantitas? ('in what is quantity received?'):

I concede that the whole human being is extended and when it is asked what is quantity received in, I say [it is received] in the composite as informed by corporeal form. And when it is argued that accordingly the form is extended I say that this is true with regard to that which is the proximate and immediate ratio of receiving extension but this does not apply to a form if it is a first and principal [form]. Again it is by equipollence that [the form] may be in each extended part of the composite. ${ }^{118}$

Again, Baconthorpe insists that the rational soul is wholly present in the whole and whole in every part without being accidentally extended realiter ('in fact'). The rational soul is the first and principal form of the body. It is in this way remote. Corporeal form together with matter are the proximate and immediate rationes of receiving extension; that is what they are fitted to do.

The Carmelite master advances several other arguments along the same lines. He talks of a newly-created hand - part of the human composite. The hand lives ("is alive') by means of the rational soul which precedes it, not in a way that the soul freshly (noviter) pours itself into the hand, but in such a way as it extends itself through the totality, so that it may be whole in individual parts. Furthermore, with an acknowledgement of the place of the human being in the hierarchy of substances, Gerard says the following:

I concede that the human being as inferior and contained under a body according to the kind of substance it is, is per se extended. And equally I concede the point when we are talking about matter and the corporeal form - they are extended (together). But now we are talking about accidental extension which is a result of quantity (as an accident) and this is not the issue in hand. ${ }^{119}$

Finally, Baconthorpe reiterates the point he is making:

${ }^{118}$ Concedo quod totus homo est extensus. Et quando quaeritur, in quo recipitur quantitas? Dico quod in composito ut informatur forma corporeitatis. Et quando arguitur: igitur forma extenditur: Dico quod verum est de forma, quae est proxima, et immediata ratio recipiendi extensionem, non tamen oportet de forma si sit solum prima ratio, et principalis, sed sufficit aequipollentia, quod scilicet ita vere sit in qualibet parte extensa, ac si extenderetur (115b116a).

${ }^{119}$ Concedo quod homo inquantum inferius et contentum sub corpore de genere substantiae est per se extensus. Et quando dicitur, igitur partes essentiales eius extenduntur, scilicet materia et forma corporeitatis; concede, sed loquimur nunc de extensione accidentali, quae est per quantitatem: et sic nihil est ad propositum. (116a) 
When it is said that the soul surpasses matter as matter's act and for the same reason is able to be extended along with it, I say it is only true if in an equipollent and more excellent way it can be the perfection of material. It can be in any part of the body without being extended by it. It is whole in whole and whole in each part. ${ }^{120}$

At this point in the proceedings Baconthorpe introduces a potential objection to his argument from equipollence:

It is possible to dispute my main point: I have been saying that these problems are apparently solved by equipollence. Nonetheless the principal difficulty remains: what in the nature of things could be such equipollence, namely that some form may be whole in any divided part and extended in some divisible thing without nevertheless the informing form being divided or extended. ${ }^{121}$

In reply to this potential objection Baconthorpe illustrates his position using an analogy from geometry: that of a flowing point as the substantial form of a line. ${ }^{122}$ Here the Carmelite master demonstrates, once again, the willingness of English thinkers to employ insights from the exact sciences within the context of philosophical and theological discussion:

I argue that this issue is best dealt with by means of the example of a point. Let us suppose a point is the substantial form of a line, just as the geometers suppose that a flowing point causes a line. If we add to this supposition that the point in no way can be divided neither according to location, nor according to position, nor according to extension, nor in any other conceivable way, it follows that a point is a substantial form of the line, which is whole in the whole line. So it is with the case in hand [concerning the rational soul]. ${ }^{123}$

${ }^{120}$ Quando dicitur quod anima ita supergreditur materiam, quod est actus materiae, et eadem ratione potest extendi cum ea: Dico quod verum est nisi quodam aequipollenti modo, et excellentiori posset esse perfectio materiae. Et hoc dico, quod habet inquantum potest esse cuiuslibet partis forma sine extensione per hoc, quod est tota in toto, et tota in qualibet parte. (116a).

${ }^{121}$ Contra praemissam responsionem generalem potest dubitari: Dicetur enim quod ista argumenta sunt apparenter soluta per hoc, quod dictum est de aequipollentia, sed nihilominus remanet principalis difficultas, qualiter in rerum natura potest esse aequipollentia talis, videlicet qualiter est possible, quod aliqua forma sit tota in qualibet parte divisa, et extensa alicuius rei divisibilis, et tamen quod illa forma informans nullo modo sit divisa, aut extensa. (116b).

${ }^{122}$ Margartet Baron points to the discussion of flowing points and the forming of lines in the writings of Nicole Oresme (c.1320-1382) and the fourteenth-century Oxford Calculators among whom the terms fluxus and fluens had currency. See M. Baron, The Origins of the Infitesimal Calculus (Oxford: Pergamon Press 1969), p. 84.

${ }^{123}$ Dico quod illud est declaratum superius per exemplum de puncto. Supponamus enim quod punctus esset forma substantialis lineae (sicut supponunt Geometrae, quod punctus fluens causat lineam) si post addamus huic suppositione quod punctus nullo modo potest dividi nec secundum situm, nec secundum positionem, nec secundum extensionem, nec quocumque alio modo cogitabili, sequitur quod punctus sic est forma substatinalis lineae, quod est totus in tota linea, et totus in qualibet parte. (116b). 
Baconthorpe concludes the first article by summarising his position on the question in hand. He insists in the final analysis that one can bring forward compelling arguments for the position that the soul is present whole and undivided in the whole and in each part of the human being. To seek more is, Baconthorpe asserts, to look for 'a knot in a bulrush', that is to look for a problem where there is none:

Concerning the case in question, I argue that the rational soul is whole in the whole, and wholly undivided in each part, and unextended, this is not provable by means of those things which are joined with it and other substantial forms and, thus, to procede in a probative and affirmative way because in many things it flees the nature of other forms. We suppose as a matter of faith or from Philosophy or both that the rational soul cannot be divided neither according to location, nor according to position, nor according to extension, nor in any other conceivable way either by faith or philosophy or both. It follows, therefore, that thus is our form, that it is whole, undivided in each of our parts and anyone who looks for more proof in such things, is looking for a knot in a bulrush (nodum in scirpo). ${ }^{124}$

\section{Article 2}

Elsewhere in his Sentences commentary Baconthorpe has extended discussion intended to prove the plurality thesis with regard to substantial form. In the present question he gives his brief article 2 over to a consideration of what kind of position concerning the soul and extension one would be committed to if one were to insist on the unicity of substantial form. He clearly has Thomas Aquinas in mind and, indeed, cites him explicitly. The text referred to is from Thomas's Summa Ia, q. 76, art. 4. On Baconthorpe's reading, Thomas's insistence on identifying corporeal form and the rational soul as one necessitates that one introduce a kind of 'graduated' view of unique substantial form:

It has to be said that although they are one form, [proponents of this view] speak nevertheless of different degrees (gradus) in the same form. And so the question concerning the identity of the rational soul with corporeal form becomes a question concerning the degrees of forms and this is accepted by Thomas in the first part of his Summa where he addresses the question. Following this line one has to say that the [soul] is extended accidentally by reason of the grade of corporeity and remains unextended by reason of intellectuality. ${ }^{125}$

${ }^{124}$ Ad propositum dico, quod animam intellectivam esse totam in tota, et totam in qualibet parte indivisam, et inextensam, non potest hoc probari faciendo probationem per ea, quae sibi, et aliis formis substantialibus conveniunt; et sic procedere via probativa, et affirmativa, quia in multis fugit naturam aliarum formarum. Supponimus enim ex fide, vel ex Phylosophia, vel ex utraque; quod anima non potest divide nec secundum situm, nec secundum positionem, nec secundum extensionem, vel quocumque modo cogitabili, ut ex fide, vel ex Phylosophia habemus, vel ex utraque. Sequitur igitur quod sic est forma nostril, quod ipsa est totat, et indivisa in qualibet parte nostri: Et qui quaerit aliam declarationem in talibus, quaerit nodum in scirpo. (117a).

${ }^{125}$ Respondendum est quod licet sunt una forma, dicunt tamen diversos gradus in eadem forma et ideo ista quaestio de identitate intellectivae cum corporeitate consuevit vocari quaestio de gradibus formarum, et accipitur a Tho. prima parte Summae, ubi quaerit istam 
This is an issue to which Baconthorpe intends to return in the future. For the moment he 'holds his fire' and refrains from pouring scorn on the Angelic doctor's position. Just to note in passing that the doctrine of the real presence of the Eucharist makes a very brief appearance in article 2 only to be dismissed as (for the moment) irrelevant to the philosophical discussion in hand: Sed illud exemplum est fidei: bic autem loquimur physice; Igitur non valet (117a). Baconthrope is in the present text content to confine himself to philosophical discussion.

\section{Article 3}

It was noted earlier that Baconthorpe frequently settles an argument secundum Philosophum with the help of Averroes the Commentator. True to form, we find a classic example of Baconthorpe's preferred way of settling an argument in article three of the quaestio we have been considering. The entire article, which is intended to settle or 'determine' the issue of the rational soul and spatial extension pivots around two extracts from Aristotle's Physics. He will also supply some further argumentation from Aristotle's De anima. The early modern editor of Baconthorpe's text summarises his intent as follows:

[Baconthorpe] teaches that the rational soul, as a form informing the body, is nevertheless not extended unto the extension of the body, whence he explains the demonstration of Aristotle in Book VIII of the Physics, by which he proves that Intelligence is not in magnitude. ${ }^{126}$

And so Baconthorpe asks: Quomodo posit anima intellectiva non extendi extensione corporis? ('In what way can the rational soul not be extended unto the extension of the body?').

True to form, Baconthorpe sets out to conclude his discussion secundum Philosophum but not before he admits that Aristotle puts forward an argument in Book VIII of his Physics $(266 a 10 ; 267 b 19-26)$ that could be seen to prove that the rational soul is extended in the extension of the body of which it is a form. He summarises Aristotle's argument in the form of a syllogism:

Major: The First Intelligence (the 'Unmoved Mover') cannot exist in magnitude because then it would be dividable into parts and the whole of its very magnitude and thus a part in a part of magnitude would move in shorter time and the whole which would be in total magnitude would move in longer time.

Minor: But this would not be true unless the Intelligence were extended in the extension of its subject, if it is its form.

quaestionem, et secundum hoc est dicendum quod extenditur per accidens ratione gradus corporeitatis, et manet inextensa ratione intellectualitatis.

${ }^{126}$ Docet quomodo anima intellectiva, cum sit forma informans corpus, non tamen extendatur ad extensionem corporis, unde explicat demonstrationem Aristotelis 8. Physico, qua probat Intelligentiam non esse in magnitudine. (118a). 
Conclusion: Therefore, the rational soul is extended in the extension of the body of which it is a form. ${ }^{127}$

Baconthorpe's strategy in trying to circumvent this problem is, first, to draw attention to its status as an argument and, secondly, to suggest that Aristotle's attention is directed in this case to (what Baconthorpe calls) common physical situations rather than to matters properly to do with First Intelligence (as First Intelligence). Aristotle is arguing, Baconthorpe contends, as a mere physicist (mere ut Physicus) and is not speaking simply and strictly (simpliciter et stricte).

In the first place, Baconthorpe insists that while Aristotle's views have the status of an argument they do not amount to a demonstrative proof: non est demonstratio in rei veritate (literally: 'it is not a demonstration in the truth of the thing'). Secondly, on Baconthorpe's reading, Aristotle is speaking in this part of the Physics concerning common physical situations. If we were to leave things at that level then his argumentation would suffice to show that each form received in matter is extended in the extension of matter. However, for Baconthorpe, this does not obtain in the case of what is proper to the First Intelligence or Unmoved Mover. To support his reading of Aristotle at this point and to make it applicable to the human soul, the Carmelite master adduces two references to the De anima. In De anima II (414b18-20) Baconthorpe asserts that Aristotle, dealing with the powers of the soul, argues that the rational soul is the form of the body and, as such, is that by which we primarily know. Furthermore, in De anima III (430a10-25) in that famous, enigmatic and textually problematic passage concerning the active and passive intellects, Aristotle insists (again, as Baconthorpe presents him) that the rational soul is unmixed, separate, incorruptible and impassible and that it does not lose its proper conditions when united with matter.

Baconthorpe concludes the article by reiterating his conviction that the rational soul, as a special case and when properly considered as rational, is not extended along with the extension of matter, although it is united with it within the context of the human being. Against those who would seek to deny that the rational soul is the form of the body on account of its being united with a material body, Baconthorpe argues that the rational soul, on account of its very rationality, has (and is to be asserted as having) a different mode of presence to other instances of form united with matter:

I respond as before that the first consequence holds according to the common physical propositions, according to which if something is united with matter it is divided, but this does not hold according to propositions proper to Intelligence. ${ }^{128}$

${ }^{127}$ Ubi primo dubitatur circa hoc, quia 8 Physicorum, tex. comm. 78 et 86 , arguit Phylosophus quod prima Intelligentia non potest esse in magnitudine, quia tunc posset divide secundum partes, et totum ipsius magnitudinis, sic quod pars in parte magnitudinis moveret in minori tempore, et tota, quae esset in tota magnitudine, moveret in longiori tempore. Sed istud non esset verum, nisi Intelligentia extenderetur extensione sui subiecti si esset forma eius. Igitur anima intellectiva extenditur extensione corporis, cuius est forma (118a).

${ }^{128}$ Respondeo ut prius quod prima consequentia tenet secundum propositiones communes physicas, scilicet si unitur materiae igitur dividitur, sed non tenet secundum proprias positiones de Intelligentia (119a). 


\section{Conclusion}

Although the best-known among the Carmelite scholastics, John Baconthorpe remains one of the lesser-known medieval thinkers today. In his discussion of soul, body and extension Baconthorpe reveals himself to be a clear-headed and methodical thinker, keen to engage with and contribute to the philosophical and theological discourse of his age. He is a dedicated proponent of the doctrine of the plurality of substantial form at a time and within a context when many considered it indispensable to philosophy and theology. Baconthorpe sees the potential in the doctrine for addressing the difficult question of the soul's relationship with (and 'presence in') the body. He also reflects the innovative spirit of the age in seeing the explanatory potential in employing logical terminology and insights from the exact sciences within philosophical and theological discourse; one should be reminded that 'philosophy' at that time and until the seventeenth and eighteenth centuries 'included' all the natural sciences. Baconthorpe introduces an air of 'pragmatism' to the debate in admitting that all he can hope to provide are compelling arguments regarding the relationship between the body and the soul which may not ultimately satisfy the diehard seeker after proof. His particular discussion of soul, body and extension witnesses in a significant way to the wider concerns of philosophical debate in the fourteenth century. In addition to adding to the stock of knowledge concerning late medieval thought, further study of this Carmelite master's output (along with the work of other fourteenth-century thinkers) should also in time pay dividends in enabling scholars to trace the roots of early modern philosophical discourse. 